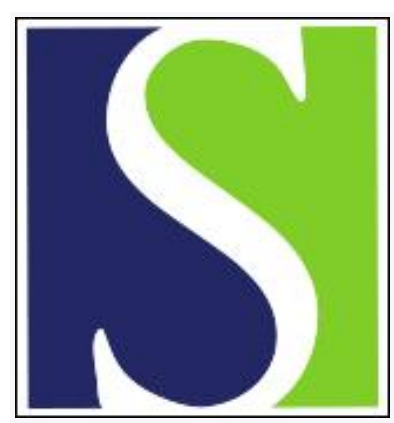

Scand J Work Environ Health 1984;10(5):293-298

https://doi.org/10.5271/sjweh.2326

Issue date: Oct 1984

Occupational asbestos exposure, lung-fiber concentration and latency time in malignant mesothelioma.

by Mowé G, Gylseth B, Hartveit F, Skaug V

This article in PubMed: www.ncbi.nlm.nih.gov/pubmed/6523093

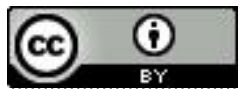




\title{
Occupational asbestos exposure, lung-fiber concentration and latency time in malignant mesothelioma
}

\author{
by Gunnar Mowé, MD, ${ }^{1}$ Bjørn Gylseth, PhD, ${ }^{1}$ Flora Hartveit, MD, PhD, ${ }^{2}$ Vidar Skaug, $M D^{1}$
}

\begin{abstract}
MOWÉ G, GYLSETH B, HARTVEIT F, SKAUG V. Occupational asbestos exposure, lung-fiber concentration and latency time in malignant mesothelioma. Scand J Work Environ Health 10 (1984) 293-298. Mineral fiber concentration in lung tissue was analyzed by scanning electron microscopy in 73 males with malignant mesothelioma and in 36 referents who died of cardio- or cerebrovascular diseases. The investigation showed apparent differences in the median lung-fiber concentration between occupational groups with different levels of asbestos exposure, as judged from their occupational history. Thus the mineral fiber content in human lung tissue provides a useful indicator of cumulative asbestos exposure. There was also a statistically significant difference between the median lung-fiber concentration among mesothelioma cases with unlikely or unknown occupational asbestos exposure and the reference group. The latency times in 42 of the cases with definite or probable occupational asbestos exposure showed a log-normal distribution with a median of 37 years and a range of $19-68$ years. No statistically significant correlation was found between the logarithm of the latency time and the logarithm of the lung-fiber concentration.
\end{abstract}

Key terms: correlation, distribution curves, mineral fiber analyses, scanning electron microscopy.

Latency time is defined in this paper as the time interval between first year of employment involving exposure to asbestos and death. Long latency time is a typical feature of malignant mesothelioma (30). Enterline (7) suggested that the latency time for asbestos-induced cancers depends on the level of asbestos exposure so that high exposure would be associated with short latency, and low exposure with long latency. However, this suggestion is without epidemiologic support.

Retrospectively it is difficult to estimate cumulative asbestos exposure $(23,29)$ even when a detailed occupational history is available. Dust level measurements are seldom available, and in epidemiologic studies past occupational asbestos exposure is therefore usually assessed from the occupational history and from knowledge concerning asbestos exposure in various occupations and trades. If information about past occupations is incomplete, the latency time cannot be estimated with certainty.

Provided exposure has been to amphibole asbestos, lung-fiber concentration is probably one of the best indicators of cumulative asbestos exposure (4, $19,25)$ and may as such provide an opportunity to study the association between latency time and cumulative asbestos exposure. Mineral fiber analyses of

\footnotetext{
1 Institute of Occupational Health, Oslo, Norway.

2 Department of Pathology, the Gade Institute, University of Bergen, Bergen, Norway.
}

Reprint requests to: Dr G Mowé, Institute of Occupational Health, PO Box 8149-Dep, Oslo 1, Norway. lung tissue have, in recent years, attracted great interest from a methodological, epidemiologic, and a medicolegal point of view. So far no standardized analytical methods have been established, and thus a comparison of results from different studies may be of limited value (25). In order to identify and measure the smallest asbestos fibers, transmission electron microscopy linked with X-ray microanalysis and selected area electron diffractometry seems to be the method of choice. However, because of its complexity and cost, other methods such as optical microscopy and scanning electron microscopy are frequently employed techniques. These methods are justified as long as their limitations are accepted and the intermethodological variations are well documented. In a recent report by Rogers (25) many of these analytical issues have been thoroughly reviewed.

The objectives of the present investigation were as follows: (i) to investigate the association between exposure to asbestos, as judged from occupational histories, and mineral fiber concentration in lung tissue and (ii) to assess the correlation between latency time and mineral fiber concentration in lung tissue in malignant mesothelioma.

\section{Materials and methods}

\section{Cases and referents}

The cases were collected in 1978-1983. During this period lung tissue samples from 73 men with malig- 
nant mesothelioma were provided from pathology departments and analyzed by scanning electron microscopy. The diagnosis was, in all cases, based on autopsy. Five of the cases were recorded by the Can-

Table 1. Survey of occupations and lung-fiber concentrations of 73 men with malignant mesothelioma.

\begin{tabular}{|c|c|c|c|c|c|}
\hline \multirow[t]{2}{*}{ Group } & \multirow[t]{2}{*}{ Occupation } & \multirow[t]{2}{*}{ Number } & \multicolumn{3}{|c|}{$\begin{array}{l}\text { Lung fiber concentra- } \\
\text { tion (million per gram } \\
\text { of dried tissue) }\end{array}$} \\
\hline & & & Mediar & $n$ & Range \\
\hline I & $\begin{array}{l}\text { Insulation workers } \\
\text { Asbestos-cement } \\
\text { workers } \\
\text { Chemical maintenance } \\
\text { workers }\end{array}$ & $\left.\begin{array}{l}3 \\
5 \\
2\end{array}\right)$ & 10 & 83 & $15-490$ \\
\hline II & $\begin{array}{l}\text { Construction workers } \\
\text { Work shop employees, } \\
\text { workers in heating } \\
\text { trades } \\
\text { Shipyard workers, } \\
\text { machine crew }\end{array}$ & $\begin{array}{r}13 \\
9\end{array}$ & 38 & 6.1 & $0.5-62$ \\
\hline III & $\begin{array}{l}\text { Skilled workers } \\
\text { Various industrial } \\
\text { workers } \\
\text { Service workers clerks } \\
\text { Other occupations, } \\
\text { unknown }\end{array}$ & $\begin{array}{l}6 \\
7 \\
7\end{array}$ & 25 & 1.8 & $0.1-6.1$ \\
\hline Total & & & 73 & 3.4 & $0.1-490$ \\
\hline Refere & ents & & 36 & 0.3 & $0-4.8$ \\
\hline
\end{tabular}

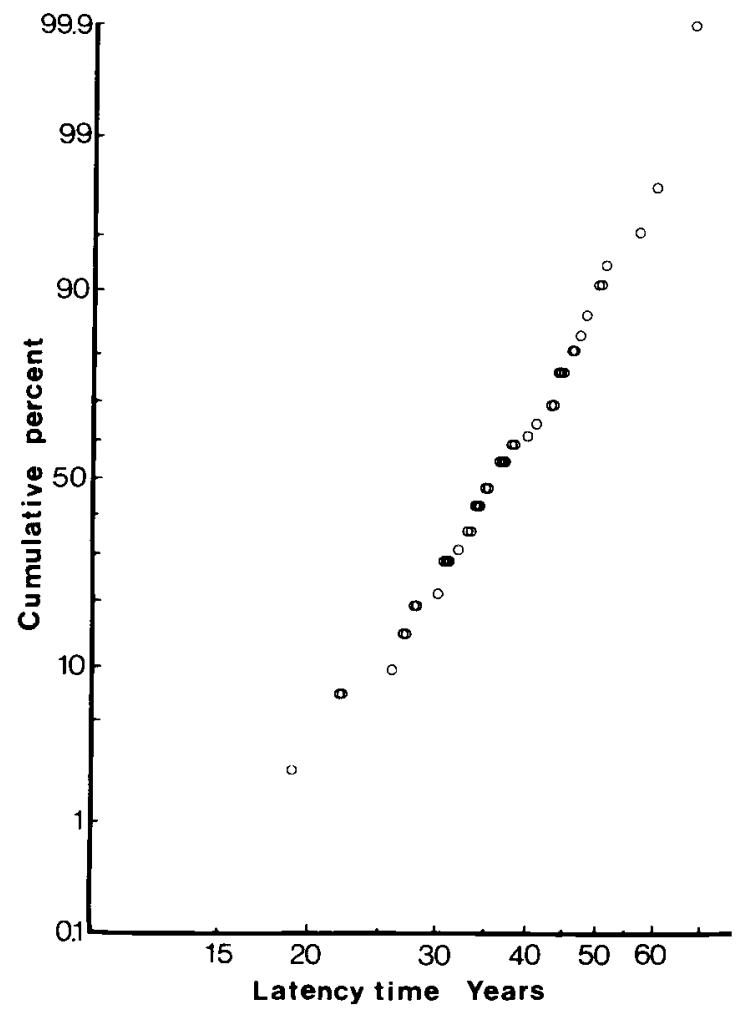

Figure 1. Distribution of latency times for 42 of the cases of malignant mesothelioma in occupational groups I and II. cer Registry before 1970, 53 cases between 1970 and 1979 , and 15 cases after 1980 . Some of the cases have been included in previous publications $(11,12,20$, 22).

For all the cases autopsy reports and medical records were available. Information about occupational history was obtained from the following sources: local social insurance offices, hospital records and autopsy reports, and specialists in occupational medicine (11 cases), as well as by personal interviews ( 7 cases). Thus, for 18 cases a detailed occupational history based on interview by a qualified physician was available, but for the others past occupational exposure had to be evaluated from the available employment records, particularly from those of the social insurance offices. Direct contact with the dependents was not permitted by the health authorities.

The cases were categorized into three occupational groups according to occupational information. Group I consisted of insulation, asbestos-cement, and chemical maintenance workers with evidence of high occupational asbestos exposure, both to crocidolite and chrysotile, as judged from the occupational history. Group II comprised cases in occupations for which an increased incidence of malignant mesothelioma has been reported (17). In this group occupational asbestos exposure was highly probable, but the level of exposure was generally lower than in group I. Furthermore, we had no definite information about the fiber types. Group III consisted of cases in occupations with unlikely or unknown exposure to asbestos. The analysis of the association between occupation and the lung-fiber concentration was based on the total material of 73 cases.

The first year of employment in the first job with definite or probable asbestos exposure was chosen as the indicator of the first year of exposure. Some cases had changed jobs several times in the distant past, including jobs in which asbestos exposure might have varied considerably. In these cases the latency time could have been either under- or overestimated. Particularly in group III both the occupational exposure and the latency time were difficult to evaluate due to incomplete information. In order to improve the validity of the latency time/lung-fiber concentration analysis, this part of the investigation was restricted to 42 cases -10 cases in occupational group I and 32 cases in occupational group II. For these 42 cases the evidence of occupational asbestos exposure was definite or probable, and the latency times could be estimated with reasonable certainty.

The referents consisted of 36 persons selected on the basis of these criteria. One group of 28 referents was matched by sex, age, and year of death to 14 mesothelioma cases from one pathology laboratory in a case-referent study which will be published separately (Mowé et al, in preparation). The other group of eight referents was obtained from consecutive hospital autopsies from another pathology department. 
It represents a group selected on the basis of age and causes of death, and it has been included in a previous investigation (12). For all the referents autopsy reports, medical records, and information about past occupations were obtained from the local social insurance offices. The causes of death among the referents were cardio- and cerebrovascular disease. Lung tissue samples for fiber analyses were obtained from all the referents.

\section{Analytical procedures}

The sampling of the lung tissue was not standardized, and the tissue samples comprised both formaldehydepreserved and paraffin-embedded material. In the former case small pieces were cut and dried overnight; in the latter this procedure was followed after a melting/deparaffinization step. The dried pieces were weighed and ashed following procedures described previously (10). On the basis of previous documentation, scanning electron microscopy was chosen for determining total fiber concentrations. In a recent study it has been shown that amphiboles are the predominant mineral fibers (13) in lung tissue samples, and through interlaboratory comparisons it has been demonstrated that the scanning electron microscopic method is adequate for total number determinations.

\section{Statistical methods}

The difference between the latency times and lungfiber concentrations in various subgroups was assessed by a nonparametric statistical method, the MannWhitney two-sample test. The correlation coefficients were assessed according to Armitage (2).

\section{Results}

Table 1 gives an overview of the occupations and the lung-fiber concentrations for both the cases and the referents. The mean age at death was 67.0 (SD 9.5, range $41-92$ ) years for the cases and 67.9 (SD 10.9, range $42-90$ ) years for the referents. The differences in the median lung-fiber concentration of group II was only one-tenth of the median of group I, but it was three times the median of occupational group III. The differences were statistically significant. The difference between the median lung-fiber concentration of group III, with unknown or unlikely asbestos exposure, and the reference group was also statistically significant ( $p<0.01$ ). Five of the referents had been employed in group II occupations, and they all had fiber concentrations exceeding 2.0 million per gram of dried tissue.

Study of the correlation between the latency time and the lung-fiber concentration was restricted to 42 cases in occupational groups I and II. Figure 1 shows that the latency times approximate a log-normal distribution with a median of 37 years and a range of 19-68 years.

These 42 cases were divided into three subgroups according to lung-fiber concentration, $\leq 1.9,2.0-$ 9.9 , and $\geq 10$ million fibers per gram of dried tissue. Table 2 provides information on the age and year at first exposure, latency time, and age at death for the cases in the three subgroups. None of the variables differed statistically significantly between any of the three subgroups. The correlation coefficient ( $r$ ) was calculated for every pair of exposure variables. The highest coefficients were found between the latency time and the year of first exposure $(r=-0.9, p<$ $0.001)$ and the age at first exposure $(\mathrm{r}=-0.65, \mathrm{p}<$ 0.001 ). There was no correlation between the logarithm of the latency time and the logarithm of the lung-fiber concentration $(r=-0.088, p=0.58)$.

Figure 2 shows the distribution of the latency times for the three subgroups on a logarithmic scale.

\section{Discussion}

Variation in deposition, clearance rate, durability, and retention of different types of asbestos fibers is

Table 2. Year and age at first exposure, latency time, and age at death for 42 men with malignant mesothelioma in occupational groups I and II with definite or probable occupational asbestos exposure and known latency times. (Number of cases in parentheses)

\begin{tabular}{|c|c|c|c|c|c|c|c|c|c|c|c|}
\hline \multirow{2}{*}{$\begin{array}{l}\text { Fiber } \\
\text { concentration } \\
\text { subgroup }\end{array}$} & \multicolumn{2}{|c|}{ Year at first exposure } & \multicolumn{3}{|c|}{$\begin{array}{c}\text { Age (years) at first } \\
\text { exposure }\end{array}$} & \multicolumn{3}{|c|}{ Latency time } & \multicolumn{3}{|c|}{ Age (years) at death } \\
\hline & Mean & Range & Mean & SD & Range & $\begin{array}{l}\text { Geo- } \\
\text { metric } \\
\text { mean }\end{array}$ & In SD & Range & Mean & SD & Range \\
\hline $\begin{array}{l}\leq 1.9 \times 10^{6} \text { fibers } / g \text { of } \\
\text { dried tissue } \\
(N=6)\end{array}$ & 1937 & $1915-1948$ & 28.2 & 12.0 & $13-42$ & 37.4 & 0.30 & $27-57$ & 66.7 & 8.9 & $52-78$ \\
\hline $\begin{array}{l}2.0-9.9 \times 10^{6} \text { fibers } / g \text { of } \\
\text { dried tissue } \\
(\mathrm{N}=19)\end{array}$ & 1939 & $1921-1953$ & 28.0 & 10.4 & $16-45$ & 36.7 & 0.27 & $22-60$ & 65.5 & 8.7 & $49-77$ \\
\hline $\begin{array}{l}\geq 10^{7} \text { fibers } / g \text { of } \\
\text { dried tissue } \\
(N=17)\end{array}$ & 1939 & $1911-1960$ & 29.6 & 9.5 & $16-47$ & 36.6 & 0.29 & $19-68$ & 67.3 & 9.3 & $54-90$ \\
\hline Total $(N=42)$ & 1939 & $1911-1960$ & 28.7 & 10.0 & $13-47$ & 36.7 & 0.28 & $19-68$ & 66.4 & 8.8 & $49-90$ \\
\hline
\end{tabular}




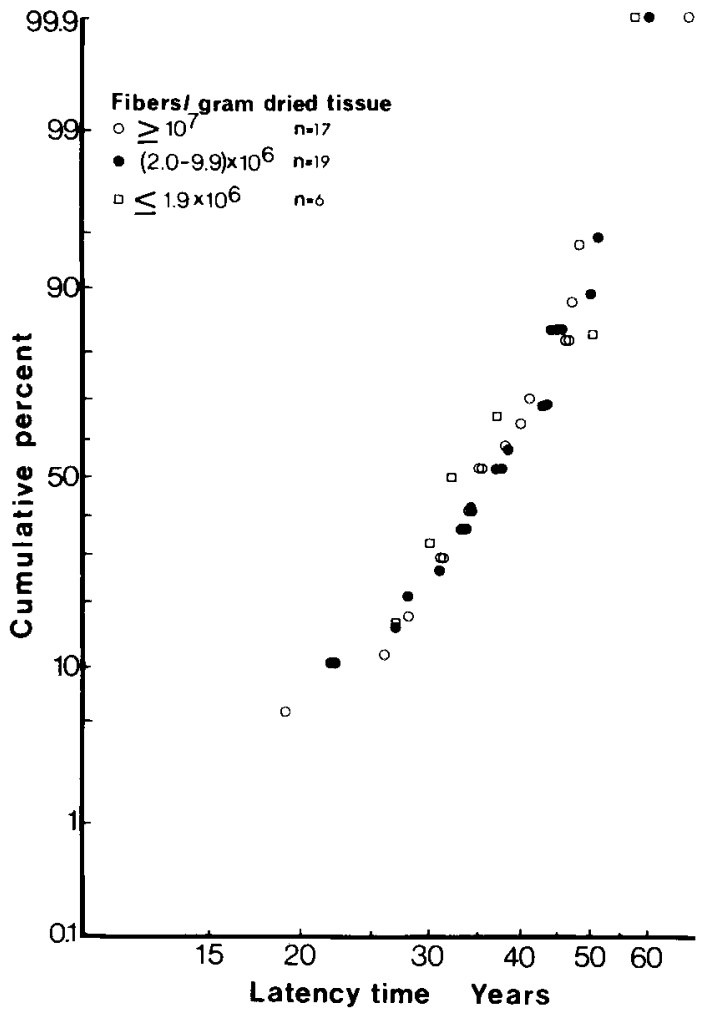

Figure 2. Distribution of latency times for 42 cases of malignant mesothelioma in occupational groups $I$ and $I 1$ according to three levels of fiber concentration in lung tissue, $\leq 1.9$, $2.0-9.9$, and $\geq 10$ million fibers per gram of dried tissue.

an important issue. Compared to amphiboles, chrysotile seems to be cleared more efficiently or even subject to chemical attack by the lung fluids $(26,32)$. These major differences are especially important as epidemiologic investigations have shown a definitely higher incidence of mesothelioma among workers exposed to crocidolite compared to among those exposed to other amphibole fibers, while the risk related to chrysotile asbestos is probably very low (6, $16,18,21)$.

Recent investigations have shown that despite high chrysotile exposure, compared to exposure to amphiboles, amphiboles are the dominating fiber type in lung tissue $(13,26)$. Thus we concentrated on analyzing the total lung-fiber concentration, with scanning electron microscopy, because we assumed that this number is probably the most important indicator of cumulative asbestos exposure. The Institute of Occupational Health, Oslo, has recently participated in two interlaboratory comparisons of asbestos analysis. The first one was arranged through the auspices of the International Organization for Standardization and comprised filtered water samples. In this study our results were close to the average for amphiboles, while we found $40-50 \%$ of the short and thin chrysotile fibers with scanning electron microscopy, compared to transmission electron microscopy. In the second study, arranged by ourselves and comprised of lung tissue samples, the results were very closely related to those found by another laboratory using transmission electron microscopy (9).

A detailed analysis, by transmission electron microscopy, of the fiber types in four of the asbestos cement workers included in occupational group I has been published before. Although the general exposure in this group of workers consisted of about $90 \%$ chrysotile and less than $10 \%$ amphibole asbestos, the lung tissue content was generally reversed (13). The loss of very thin chrysotile fibrils during scanning electron microscopy is accordingly low compared to errors which may be introduced during sampling, preparation, and counting procedures $(9$, $11,25)$.

By this method we have shown apparent differences in the median lung-fiber concentrations between occupational groups with different asbestos exposure, as judged from occupational history. There is a clear distinction between the three occupational groupings, but the distribution of lung-fiber concentration in the occupational groups does overlap considerably. The results correspond reasonably well to the assessment of asbestos exposure from occupational history, and the investigation indicates that the lung-fiber concentration is a useful indicator of cumulative asbestos exposure.

According to our method a fiber concentration of more than one to two million per gram of dried lung tissue is associated with occupational asbestos exposure. The results are consistent with those of previous investigations $(4,17,25)$. This borderline is based on a detection limit of 0.4 million and the analytical sensitivity of our method of about 0.1 million fibers per gram of dried tissue (25). However, low lung-fiber concentrations below this border should be evaluated carefully, as the fiber concentrations may vary considerably from site to site in lung tissue (5). Consequently, low fiber concentrations below this border do not exclude past occupational exposure to asbestos.

The lung-fiber concentrations among the cases overlapped those of the referents, and in 12 cases the fiber concentration was below one million per gram of dried tissue. Past asbestos exposure was unknown or unlikely in most of these cases, although it cannot be excluded for some of them. The causal significance of these low fiber concentrations is difficult to evaluate, but it may be that other additional etiologic factors are also active in mesothelioma induction (25).

The latency times approximated a log-normal distribution, which has been shown to be typical both for infectious (27) and malignant diseases $(1,31)$. The correlation between the latency time and the age and year of first exposure was, as expected, statistically significant. By extrapolation of the distribution curve the results were consistent with a lower limit of 
latency time of about 10 to 15 years; however, shorter latency times have been reported (28). In such cases the latency time could have been underestimated because of incomplete occupational history or unknown occupational or nonoccupational asbestos exposure earlier in life, or other etiologic factors may have been responsible.

Jones \& Grendon (14) suggested that the time until the appearance of cancer (the latency time) was related to the inverse cube-root of the dose. This hypothesis has been used as an argument in favor of a "practical threshold" (7). At very low exposure, the latency time was expected to be longer than the life expectancy. This hypothesis has been opposed by others $(8,23,29)$, and, in an attempt to test the hypothesis, Liddell (15) found no evidence of any correlation between the cumulative asbestos exposure (fiber years) and the latency time among chrysotile miners with bronchial cancer. In our investigation no correlation was found between the logarithm of the latency time and the logarithm of the lung-fiber concentration, a finding supporting Liddell's conclusions.

In a recent study, Browne (3) suggested that the latency time for malignant mesothelioma is distributed in a random manner in time from first exposure. He also suggested that asbestos may not act as a complete carcinogen but as a promoter and that a threshold seems probable in the induction of mesothelioma. Our results were not consistent with this hypothesis.

Forty-two of the cases with known latency times in occupational groups I and II were divided into three subgroups according to various levels of lung-fiber concentration. There was no statistically significant difference in latency time or age at death between the three subgroups. Furthermore on the log-scale the distribution curves appear normal with similar means and standard deviations in the three subgroups.

We conclude (i) that the total lung-fiber concentration analyzed by our method is a useful indicator of cumulative asbestos exposure as judged from occupational history, provided the exposure has been to amphiboles and (ii) that there is no correlation between latency time and the total lung-fiber concentration in malignant mesothelioma. This conclusion is consistent with those of other investigations (19) and conforms with the model for mesothelioma induction suggested by Peto et al (24).

\section{Acknowledgments}

We acknowledge the cooperation of the Cancer Registry of Norway and the staff of the pathological departments at the Ullevål Municipal Hospital, the Norwegian State Hospital, the Aker Municipal Hospital, the Norwegian Radium Hospital, the Telemark County Hospital, the University Hospital of Trondheim, the Buskerud County Hospital, the Østfold
County Hospital, the University Hospital in Tromsø, and the Laboratory of Pathology in Oslo for providing us with lung tissue samples and autopsy reports. We further acknowledge the National Insurance Institution, the local social insurance offices, Prof S Langård, and Dr A Wannag for their provision of occupational information.

\section{References}

1. Armenian KA, Lilienfeld AM. The distribution of incubation periods of neoplastic diseases. Am J Epidemiol 99 (1974) 92-100.

2. Armitage P. Statistical methods in medical research. Blackwell Scientific Publications, Oxford and Edinburgh 1971.

3. Browne K. Asbestos-related mesothelioma: Epidemiological evidence for asbestos as a promoter. Arch Environ Health 38 (1983) 261-266.

4. Churg A. Fiber counting and analysis in the diagnosis of asbestos-related disease. Human Pathol 13 (1982) $381-392$.

5. Churg A, Woods P. Observation on the distribution of asbestos fibers in human lungs. Environ Res 31 (1983) $374-380$.

6. Dement JM, Harris RL, Symons MJ, Shy C. Estimates of dose-response for respiratory cancer among chrysotile asbestos textile workers. Ann Occup Hyg 26 (1982) 869-887.

7. Enterline PE. Pitfalls in epidemiological research: An examination of the asbestos literature. J Occup Med 19 (1976) $150-156$.

8. Guess HA, Hoel DG. The effect of dose on cancer latency period. J Environ Pathol Toxicol 1 (1977) $279-286$.

9. Gylseth B. Analysis of asbestos fibers and asbestos bodies in human lung tissue samples: An international laboratory trial. Presented at the Workshop on the Assessment of Mineral Fibres from Human lungs, Oxford, 17-19 September 1984.

10. Gylseth B, Baunan RH, Bruun R. Analysis of inorganic fiber concentration in biological samples by scanning electron microscopy. Scand J Work Environ Health 7 (1981) 101-108.

11. Gylseth B, Baunan RH, Overaae L. Analysis of fibres in human lung tissue. $\mathrm{Br} \mathrm{J}$ Ind Med 39 (1982) $191-195$.

12. Gylseth B, Mowé G, Skaug V, Wannag A. Inorganic fibers in human lung tissue from patients with pleural plaques or malignant mesothelioma. Scand J Work Environ Health 7 (1981) 109-113.

13. Gylseth B, Mowé G, Wannag A. Fibre type and concentration in the lungs of workers in an asbestos cement factory. Br J Ind Med 40 (1983) 375-379.

14. Jones HB, Grendon A. Environmental factors in the origin of cancer and estimation of the possible hazard to man. Food Cosmet Toxicol 13 (1975) 251-268.

15. Liddell FDK. Latent periods in lung cancer mortality in relation to asbestos dose and smoking. In: Wagner JC, Davis W, ed. Biological effects of mineral fibers. International Agency for Reseach on Cancer, Lyon $1980, \mathrm{pp} 661-665$.

16. McDonald AD, Fry JS, Woolley AJ, McDonald JC. Dust exposure and mortality in an American chrysotile asbestos friction products plant. Br J Ind Med 41 (1984) $151-157$.

17. McDonald AD, McDonald JC, Pooley FD. Mineral fibre content in mesothelial tumours in North America. Ann Occup Hyg 26 (1982) 417-421.

18. McDonald JC, McDonald AD. Epidemiology of meso- 
thelioma from estimated incidence. Prev Med 6 (1977) $426-446$.

19. Morgan A, Holmes A. Concentration and characteristics of amphibole fibres in the lungs of workers exposed to crocidolite in British gas-mask factories and elsewhere during the Second World War. Br J Ind Med 39 (1982) 62-69.

20. Mowé G, Gylseth B. Medico-legal aspects of malignant mesothelioma. Scand J Soc Med 12 (1984) 15-23.

21. Newhouse ML, Berry G, Skidmore JN. A mortality study of workers manufacturing friction materials with chrysotile asbestos. Ann Occup Hyg 26 (1982) 899909.

22. Ophus E, Mowé G, Osen KK, Gylseth B. Scanning electron microscopy and $\mathrm{x}$-ray microanalysis of mineral deposits in lungs of a patient with pleural mesothelioma. Br $\mathrm{J}$ Ind Med 37 (1980) 375-381.

23. Peto R. Dose-response relationship for asbestos-related disease: Implication for hygiene standards: Part II Mortality. Ann NY Acad Sci 330 (1979) 195-203.

24. Peto R, Seidmann H, Selikoff IJ. Mesothelioma mortality in asbestos workers: Implications for models of carcinogenesis and risk assessment. $\mathrm{Br} \mathrm{J}$ Cancer 45 (1982) 124-135.

25. Rogers AJ. Determination of mineral fibre in human lung tissue by light microscopy and transmission electron microscopy. Ann Occup Hyg 28 (1984) 1-12.
26. Rowlands N, Gibbs GW, McDonald AD. Asbestos fibres in the human lungs of chrysotile miners and millers - A preliminary report. Ann Occup Hyg 26 (1982) $411-415$.

27. Sartwell $P E$. The distribution of incubation periods of infectious diseases. Am J Hyg 51 (1950) 310-318.

28. Scansetti G, Mollo F, Tiberi G, Andrion A, Piolatto G. Pleural mesothelioma after short interval from first exposure in the wine filter industry. Am J Med 5 (1984) $335-339$.

29. Schneiderman MA, Decouflé P, Brown CC. Thresholds for environmental cancer: Biologic and statistical considerations. Ann NY Acad Sci 329 (1979) 92-130.

30. Selikoff IJ, Lee DHK, ed. Asbestos and disease. Academic Press, London 1978.

31. Tassignon JP. Log normal distribution of the incubation period of liver angiosarcoma in vinyl chloride polymerization workers. J Occup Med 9 (1978) 10.

32. Wagner JC, Pooley FD, Berry G, Seal RME, Munday DE, Morgan J, Clark NJ. A pathological and mineralogical study of asbestos-related deaths in the United Kingdom in 1977. Ann Occup Hyg 26 (1982) 869-887.

Received for publication: 2 March 1984 